\title{
İş Yükünün Kadınların Psikolojik Sağlı̆̆ı Üzerine Etkisinde Ev İçi İş Bölümünün Düzenleyicilik Etkisi
}

\author{
DOI: 10.26466/opus.756225
}

$*$

\author{
Sevim Gezegen Ünlü * \\ ${ }^{*}$ Dr., Serbest Araştırmacı \\ E-Posta: sevimmgezegen@gmail.com \\ ORCID: $\underline{0000-0002-2126-5468}$

\section{Öz}

Bu çalışmanın amacı, kadınlarda iş yükü algısının psikolojik sağllk üzerindeki etkisinde ev işlerinin eşler arası dağllımının düzenleyicilik etkisini araştırmaktır. Türkiye'de 7 farklı ilde yürütülen araştırmaya farkl gelir, meslek ve eğitim düzeylerinden 814 çoklu rol sahibi (evli, çoçuk sahibi, çalışan) kadın katılmıştır. Araştırma bulgularına göre ev içi iş bölümünün dağılımında kadınlar aleyhine belirgin bir eşitsizlik söz konusudur. Ev işlerinin eşler arası dağılımında elde edilen ortalama değer 3,91'dir (5 ev içi işlerin hepsini kadınların yaptığımı, 1 ise tüm işleri erkeklerin yaptığın ifade etmektedir. Araştırma sonucunda kadınların iş yüklerini yüksek olarak alg̨ladığı (ort: 2.4) ve ev içi iş bölümünün, örneklemin \%84'ünde kadınlar aleyhine, \%15'inde eşleri ile ortak ve \%1'inde eşleri aleyhine dă̆ıldı̆̆g görülmektedir. Kadınlarda iş yükü algısı psikolojik sağlık üzerinde olumsuz bir etkiye sahiptir. Yüksek iş yükü algısı özellikle anksiyete ve depresyon tecrübe etme riskini arttırmaktadır. Ev işlerinin dă̆ılımı psikolojik sağglığın iki alt boyutu üzerinde $p<.05$ güven aralığında anlamlı etkilere ( $A \mathcal{E} D$ üzerinde $\beta: 0,051$; SIB üzerinde ise 0,095) sahiptir. Bununla birlikte iş yükünün psikolojik sağlık üzerindeki olumsuz etkisinin ev içi işlerin dă̆glımındaki eşitsizliğin artmasıyla birlikte güçlendiği görülmektedir.

Anahtar Kelimeler: Çoklu Roller, İş yükü, Ev yükü, Psikolojik Sağllk 


\title{
The Effects of Workload on Women's Psychological Health
}

\begin{abstract}
The aim of the study is to test the effect of the workload on psychological health of women with multiple roles with moderation roles of division of household labor. 814 women with multiple roles (working married mother who are from different occupaitons, levels of income, education) from seven different cities which are located at Turkey contributed this research. According to results, the division of household labor unequally distributed against women. The average is obtained in the distribution of household is 3.91 (5 indicates that all household is done by women, 1 indicates that all household is done by men). Unequal distribution is relevant for $\% 84$ of the sample. Percieve their workload as high (mean: 2,4) and division of household labor distributed as: against women \%84, equally \%15, against men \%1 of the sample. The workload has negative effects on psychological health. The increase in workload noteworthily increase the risk to experienece anxiety and depression. Besides the inequality in the division of household labor against women moderate the negative relation between workload and psychological health.
\end{abstract}

Keywords: Multiple Roles, Work Overload, Domestic Labour, Mental Health 


\section{Giriş}

Çoklu roller literatürü, geleneksel rollerin tarihsel birikimini hiç azaltamadan çalışma hayatına katıldıkları için 'kadın' başlığı altında daha geniş çaplı ele alınmış ve gelişmiştir. Kadınların geleneksel rollerinin ağırlığı altında iş hayatında kariyer inşa etme çabaları küresel ölçekte gözlemlenen bir örüntüdür. Ebeveynlik, evlilik ve çalışma hayatı alanlarında üstlenilen rollerin oluşturduğu kompozisyon, zaman ve birey sağlığı üzerindeki baskının en önemli açıklayıcıları olagelmiştir. Kadınlarda çoklu rollerin sonuçları genellikle eşitsizlikler ve çalışma hayatı merkeze alınarak tartışılmaktadır. Örneğin Goode (1960), önerdiği Rol Gerginliği Teorisi'nde, geleneksel rollerinin yükümlülüklerinde eksilme olamadan iş hayatına dahil olan kadınların, iş ve aile hayatı temelli yüksek düzey beklentileri, sahip oldukları sınırlı zaman ve enerji ile sağlıklı bir şekilde karşılayamayacaklarına ve bu nedenle psikolojik ve fiziksel sağlık sorunlarıyla karşılacaklarına işaret etmiştir. Bu varsayımı test etmek adına iş hayatı temelli birçok değişken ile psikolojik sağlık arasındaki ilişkiyi ortaya koymaya çalışan araştırmalar (Gjerdingen ve diğerleri, 2001; Rydstedt ve Johansson 1998; Britt ve Dawson, 2005; Northcott, 1980) gerçekleştirilmiştir. Diğer taraftan ev içi emeğin eşler arası dağılımının psikolojik sağlık üzerindeki etkileri ile ilgili birçok araştırma (Cleveland vd.,2015; Eek ve Axmon, 2014; Bird, 1999; Harryson vd., 2012) yapılmıştır. Ancak hem iş hem de ev yükünün kadınların psikolojik sağlıkları üzerindeki etkisini tek bir araştırma modelinde tartışan araştırmaya rastlanmamıştır. Sadece Roxburgh'ün (1977), çocuk sahibi olmanın çalışan kadınlardaki etkilerine odaklanan araştırması, bazı noktalarda literatürdeki bu boşluk ile örtüşmektedir. Yüksek iş beklentileri kadınların psikolojik sağlıkları üzerinde olumsuz etkilere neden olmakta, eşlerin destekçi olmadığı durumlarda ise psikolojik sağlık üzerindeki olumsuz etki artmaktadır (Roxburgh, 1977). Bu araştırmada ise iş beklentilerinden ziyade kadınların iş yükünün nasıl algılanıldığına ve eşlerin ne kadar destek olduğundan ziyade spesifik ev işlerinin eşler arası nasıl paylaşıldığı sorularına cevap getirilmeye çalışılmaktadır. Ayrıca ev içi işlerin eşitsiz dağıldığı Türkiye'de (TÜİK, Zaman Kullanım Araştırması, 2014, 2015) iş yükü algısının psikolojik sağlık üzerindeki etkisini araştırmak literatüre katkı sağlayacaktır. Kadınlarda çoklu rollerin bir aradalığının psikolojik sağlık üzerindeki etkilerini tartışmak bu araştırmanın temel amacıdır. Bu amacı gerçekleştirmek için çalışma hayatının beraberinde getirdiği iş yükünün kadınlar tarafından nasıl alg1landığı; ev bağlamındaki üstlenilmesi gereken yükün eşler arası nasıl payla- 
şıldığı ve son olarak bu yüklerin kadınların psikolojik sağlıklarını nasıl etkilediği analiz edilmiştir.

\section{Evde ve İşte "Çalışmak": Çoklu Roller ve Sonuçları}

Genellikle annelik, ücretli bir işte çalışma ve evlilik rolleri bağlamında ele alınan çoklu rollerin psikolojik ve fiziksel sağlık üzerinde ortaya çıkardığı sonuçlar zengin bir literatür ile tartışılmaktadır (Gove ve Tudor, 1973; Nathanson, 1980; Arber vd., 1985; Reskin ve Coverman, 1985; Froberg vd., 1986; Verbrugge, 1986; Waldron ve Jacobs, 1988; Waldron vd., 1998; Arber, 1997; Ahmad-Nia, 2002; Dökmen, 2003; Etiler, 2016). Elde ettikleri sonuçları itibari ile araştırmalar, pozitif ve negatif yaklaşımlar şeklinde gruplandırılmış ve kavramsallaştırılmıştır (Baruch ve Barnett, 1986, s.578; Froberg vd., 1986). Pozitif yaklaşımlar, çoklu rollerin Rol Ayrıcalıkları, Tampon Roller Yoluyla Genel Statünün Güvenliği, Statü Zenginleşmesi, Kişilik Zenginleşmesi ve Ego Tatmini yoluyla psikolojik ve fizyolojik sağlık üzerinde olumlu etkileri olacağını savunan "Rol Birikimi Teorisi" (Sieber, 1974); çoklu rollerin özgüven, sosyal ve finansal kaynaklar ve tatmin gibi firsatların artışını sağlayarak olumlu sonuçlar doğuracağını savunan "Rol Genişlemesi Teorisi" (Sorensen ve Verbrugge,1987); ve rol artışı ile rollerin ve rol gereksinimlerinin kişinin yaşamına amaç, anlam ve rehberlik ederek umutsuzluğu, "düzensiz davranışları" azaltacağını, enerjilerini arttıracağını vurgulayan "Rol Artışı Teorisi" (Thoits, 1983) şeklinde sıralanabilir.

Negatif yaklaşımlar, kadınların ücretli bir işte çalışmalarıyla birlikte, ev içinde veya çocuk bakımı gibi sorumluluklarında esasen bir değişiklik olmayacağı sebebiyle, çatışma, aşırı rol yükü, yorgunluk, tükenmişlik ve nihayetinde hastalıklar ile yüzleşeceğini savunan "Çoklu Rol Hipotezi" (Goode, 1960; Merton, 1957); insanların çoklu rollerinin gerekliliklerini yerine getirecek kadar zamanları ve kaynakları olmaması sebebiyle rol gerginlikleri ve çatışmaları yaşanacağını varsayan "Kıtlık Hipotezi" (Goode, 1960; Marks, 1977); ve son olarak çoklu rollerin, aşırı talepler nedeniyle, kadınların sınırl zaman, enerji ve psikolojik kaynaklarını tüketip, stres düzeyinin artmasına ve sağlık üzerinde olumsuz etkiler doğurabileceğini öne süren "Rol Gerginliği Hipotezi" (Goode, 1960; Waldron ve Jacobs, 1989:3; Verbrugge, 1986) şeklinde suralanabilir.

Negatif yaklaşımlar, kadınların yüzleştiği olumsuz sonuçların hangi koşullarda ortaya çıktığını da tartışmaktadır. Bu kapsamda, ebeveyn kontrolü gerektiren yaşta çocuk ve çok sayıda çocuk sahibi olmak, tek ebeveynlik, ev 
içi işler için birincil sorumluluğa sahip olmak çoklu rol sahibi kadınların yaşadıkları stresi arttırmaktadır (Dennerstein, 1995:506). Gelir açısından bakıldığında, asgari ücretli olarak çalışan ve herhangi bir desteği olmayan genç bir anne, farklı sosyal destek olanaklarına sahip olabilen orta sinıftan çalışan bir anneye göre kişisel olarak daha fazla yıpranmaktadır (Bernstein, 2001, s.174).

Çoklu rollerin birey üzerindeki sonuçlarında gözlemlenmeye çalışılan önemli bir alan psikolojik sağlıktır. Dünya Sağlık Örgütü (DSÖ) psikolojik sağlı̆̆1; bireylerin kendi yeteneklerini gerçekleştirdiği, günlük hayatta karşılaştığı stresle baş edebildiği, üretken çalışabildiği ve topluma katkı sağlayabileceği iyi hal durumu olarak ifade edilmektedir (DSÖ, 2018).

\section{İş Yükü ve Psikolojik Sağlık İlişkisi}

Literatürde çoklu rol kompozisyonunun merkezinde çalışma hayatı yer almaktadır. Çalışma hayatındaki gerekliliklerin objektif ağırlığı kadar bu işlerin birey algısındaki karşıllğı da önemlidir. İş yükü kavramı bireylerin işyerinde üzerine almak zorunda oldukları sorumluluklara yönelik algılarını ifade etmektedir. Keser (2006, s.105) iş yükünü, bireylerin işyerinde yüklendikleri işin normalin (örneğin haftalık 40 saatlik çalışma saatinin üzerinde çalışma) üzerinde olduğuna yönelik algısı olarak tanımlarken, Qureshi ve diğerleri (2013, s.766), bir çalışana belirli bir zamanda yapması için tahsis edilen iş miktarı olarak aktarmıştır.

Günümüz çalışma hayatında, özellikle özel sektörde, bireylerin günde ortalama 10-12 saat çalıştıkları göz önünde bulundurulduğunda, bireyde iş yükü algısının oluşması beklenebilen bir sonuçtur. İş yükü algısı bireyin zihinsel ve fiziksel sağlı̆̆ kadar performansını ve verimini de etkilemektedir (Dağdeviren ve diğerleri, 2005, s.518). Gjerdingen ve diğerleri(2001, s.15) Amerika, İsveç ve Hollanda'da gerçekleştirdikleri karşılaştırmalı çalışmada, iş yükünün özellikle kadınlarda kardiyovasküler hastalık, kas-iskelet sistemi rahatsızları, depresyon ve anksiyete gibi fiziksel ve psikolojik sağlıkta bozulmalara neden olduğu tespitinde bulunmuşlardır. Ayrıca Geurts'a göre (2003, s.552) iş yükü, bireylerdeki olumsuz duyguları ortaya çıkarmakta, bireylerin kendilerini öfkeli hissetmesine, daha kolay hastalanmalarına, hayal kırıklıklarına uğramalarına ve de huzursuzluk yaşamalarına neden olmaktadir.

Rydstedt ve Johansson'ın (1998) kadın ve erkek otobüs şoförleri ile gerçekleştirdiği araştırmada, 18 ay süresince iş yükünde meydana gelen deği- 
şikliklerin işin yapılması için gereken çaba ve yorgunluk üzerinde güçlü bir etkisi olduğu tespit edilmiştir. Aynı çalışmada iş yükünün artmasının, iş sebebiyle bireylerde tükenmenin artmasına, evde rahatlamada zorluklar, evdeki taleplerle başa çıkmada ve boş zaman kullanımında sorunlara sebep olduğu görülmektedir.

Glynn, Maclean, Forte ve Cohen'in (2009, s.220) Kanada'da farklı rolleri aynı anda yerine getiren (annelik, evlilik ve çalışma hayatı) 716 kadın ile gerçekleştirdikleri araştırmaya göre çok fazla rol yüküne maruz kalmak kadınların psikolojik sağliklarının kötüye gitmesine sebep olmaktadır. Araştırmanın diğer bulgularına göre haftalık 40 saat ve altında çalışan, hane içi geliri en yüksek düzeyde olan ve yüksek düzey evlilik tatmine sahip kadınların en iyi düzeyde psikolojik sağlık seviyesine sahip oldukları görülmektedir.

Northcott (1980) evli ve çalışan kadınların -ki özellikle çocukları olanların- aşırı iş yükü ve rol çatışması sebebiyle psikolojiklerinin daha fazla risk altında olduğunu gözlemlemiştir. Araştırmanın en güçlü bulgularından biri evli kadınların evli erkeklerden daha fazla psikolojik stres altında olduklarıdir (Northcott, 1980, s.401). Dugan ve Barnes-Farrell'in (2018, s.11) 440 çalışan anne ile gerçekleştirdikleri araştırma neticesine göre, kadınların iş sonrası ev ve aile ile ilgili yükleri kendileri için daha kısıtlı zaman ayırabilmelerine sebep olmakta ve bu da öz bakım için zamanlarının kalmamasına ve daha fazla stress yaşamalarına neden olmaktadır.

\section{Ev İçi İş Bölümünün Eşler Arası Dağılımı ve Psikolojik Sağlık İlişkisi}

Ev içi işler, çocukların yetiştirilmesini, aile büyüklerinin fiziksel ve manevi olarak bakımını içermekle birlikte (Lordoğlu ve Özkaplan, 2005:257) “kadınların görünmeyen emeği” (Dedeoğlu ve Öztürk, 2010; Memiş ve Özay, 2011; Savran ve Demiryontan, 2008) ve görmezden gelinen bir emek türü olarak tanımlanmaktadır. Diğer taraftan bu ve benzeri tanımlar duygu yönetimi gibi görünür olmayan emek türlerini görmezden geldiği için eleştirilmektedir (Shelton ve John, 1996). Çalışan kadınlar için ev içi işler "ikinci vardiya" (Hochschild ve Machung, 2012) olarak nitelendirilmektedir. Ev içi emek, aile üyelerinin ve evin devamlılığını sağlamaya yönelik harcanan ücretsiz ve görünür olmayan emek türlerinin toplamı şeklinde tanımlanabilir.

Kadınlarda ev işlerinin fizyolojik ve psikolojik sağlık sonuçları kapsamlı bir literatür inşa etmiştir. İsveç'te yürütülen bir araştırmaya göre 25-64 yaş arası kadınlarda ağır ev işlerinin kişinin standart altı bir düzeyde genel sağ- 
lık durumunu değerlendirmesinde etkili olduğu vurgulanmaktadır (Molarius vd., 2013). Bununla birlikte başlı başına ev işlerine harcanan emek, hem süre hem de yoğunluk anlamında, negatif stresin bir açıklayıcısı konumundadır (Bird, 1999).

Çalışan kadınlar için ise evde ve işte "iki vardiyayı" aynı anda yürütmek hem psikolojik hem de fizyolojik rahatsızlıklara sebep olabilmektedir. Evli olmak ve ücretli bir işte çalışmanın beraberinde getirdiği roller, sadece anne için değil aynı zamanda babalar için de negatif stres ile ilişkilendirilmiştir (Voydanoff ve Donnelly, 1999). Kadın ve erkeklerde, sosyal hayatta ve aile hayatında algılanan toplam iş yükünün stres şikâyeti kaynaklı hastalık sebebiyle işe gidememe durumu üzerinde etkili olduğu sonucu elde edilmiştir (Svedberg, Mather, Bergström, Lindfors, ve Blom, 2018).

Kadınlar için ev içi işlerin yoğunluğu ve içeriği kadar bu işlerin karı-koca arasındaki paylaşımı da önemlidir. Cleveland vd.'nin (2015) araştırmasında vurguladığı üzere, ev içi işlerin eşitsiz bir şekilde dağıldığını düşünen kadınlarda, işlerin dağılımda ve ilişkilerinde eşitlik olduğunu düşünen kadınlara oranla daha yüksek düzeyde yorgunluk, stres, fiziksel ve psikosomatik semptomlar ve depresyon gözlemlenmiştir. Bu sebeple ev içi işlerin kadınlar için ağırlığı ile birlikte işlerin dağılımındaki eşitsizlik düşüncesinin stres üzerinde etkili olduğu görülmektedir. İsveç'te kasabada yaşayan, eğitimlerini tamamlayamamış orta sınıf ailelerdeki kadınlarda ekonomik sıkıntılar ve eşleri ile aralarındaki ilişkideki eşitsizliklerin depresif mod ile ilişkili olduğu 26 yıllık araştırma sonucunda gözlemlenmiştir (Hammarström ve Phillips, 2012). Bird'ün (1999) araştırmasında ise, cinsiyetler arası depresyon farkının (kadınlar aleyhine) nedeni olarak erkeklerin ev işine düşük düzey katkı sunmaları görülmektedir. Ev içi işlerin dağılımındaki eşitsizlik ile eşler arası ilişkideki eşitsizlik algısının biraraya gelmesi, kadınlar için stres kaynağını oluşturmaktadır (Harryson, Strandh ve Hammarström, 2012).

\section{Yöntem}

Literatür taramasında görüldüğü gibi, çoklu rollerin iki önemli bağlamına ait birçok değişken ile psikolojik sağlık arasındaki ilişkiye yönelik araştırmalar mevcuttur. Ancak iş yükü algısının ev içi işlerin eşler arası dağlımına göre psikolojik sağlı üzerinde nasıl etkili olduğu sorusuna direk olarak cevap verecek bir çalışmaya rastlanmamıştır. Bu nedenle, bu araştırmada iş yükü algısı ve ev işlerinin eşler arası dağılımı ekseninde yürütülecek bir tartışmanın literatüre katkı sağlaması amaçlanmıştır. Rol gerginliği teorisi 
(Goode, 1960) araştırma modelinin dayandığı kuramdır. Rol gerginliği teorisi çerçevesinde, kadınların sahip oldukları rolleri temelinde karşılaşacaklar1 yüksek beklentiler ve yükümlülükler sebebiyle psikolojik sağlıklarının olumsuz etkileneceği ve ev içi işlerin kadınlar aleyhine eşitsiz dağıldığında bu olumsuz etkinin artacağı araştırmanın temel varsayımıdır.

Araştırma modelinin açıklayıcılığını arttırabilmek için bağımlı değişken (psikolojik sağlık) üzerinde etkili olabilecek kontrol değişkenleri de dikkate alınmıştır. Hamilelik sürecinden başlayarak doğum sonrası ilk yılın sonuna kadar gözlemlenen 437 kadında aşırı iş yükünün depresyon, anksiyete, öfke ile ilişkili olduğu sonucuna ulaşılmıştır (Klein, Hyde, Essex, ve Clark, 1998). Amerika Birleşik Devletler'inde gerçekleştirilen bir araştırmada, ilk kez hamile kalan 436 kadında, doğum sonrası ilk 6 ay sona ermeden işe başlayan ve uzun saatler çalışan kadınlarda zayıf psikolojik sağlık sonuçları gözlemlenmiştir (Gjerdingen ve Chaloner, 1994). Bu noktadan hareketle çocuk say1sı kontrol değişkeni modele dahil edilmiştir. Ev içi işlerinin eşler arası dağılımı ile çocuk sayısı arasında bir ilişki olabileceği, çocuk sayısındaki artışın ve ebeveyn kontrolü gerektiren yaşta çocuk sahibi olmanın psikolojik sağlık üzerinde etkileri bu kontrol değişken ile izlenmek istenmiştir. Bu çerçevede oluşturulan araştırma modeli Şekil 1'de, hipotezler ise aşağıda paylaşılmıştir.

- H1. İş yükü algısı psikolojik sağlık üzerinde olumsuz etkilidir.

- H1.1. İş yükü algısı psikolojik sağlığın anksiyete ve depresyon boyutu üzerinde olumsuz etkilidir.

- H1.2. İş yükü algısı psikolojik sağlığın sosyal işlev bozukluğu boyutu üzerinde olumsuz etkilidir.

- H2. Ev işlerinin dağılımının düzenleyicilik etkisi, iş yükü algısının psikolojik sağlık üzerindeki olumsuz etkisini arttırmaktadır.

- H2.1. Ev işlerinin dağılımının düzenleyicilik etkisi, iş yükü algısının psikolojik sağlığın anksiyete ve depresyon boyutu üzerindeki olumsuz etkisini arttırmaktadır.

- H2.2. Ev işlerinin dağılımının düzenleyicilik etkisi, iş yükü algısının psikolojik sağlığın sosyal işlev bozukluğu boyutu üzerindeki olumsuz etkisini arttırmaktadır. 


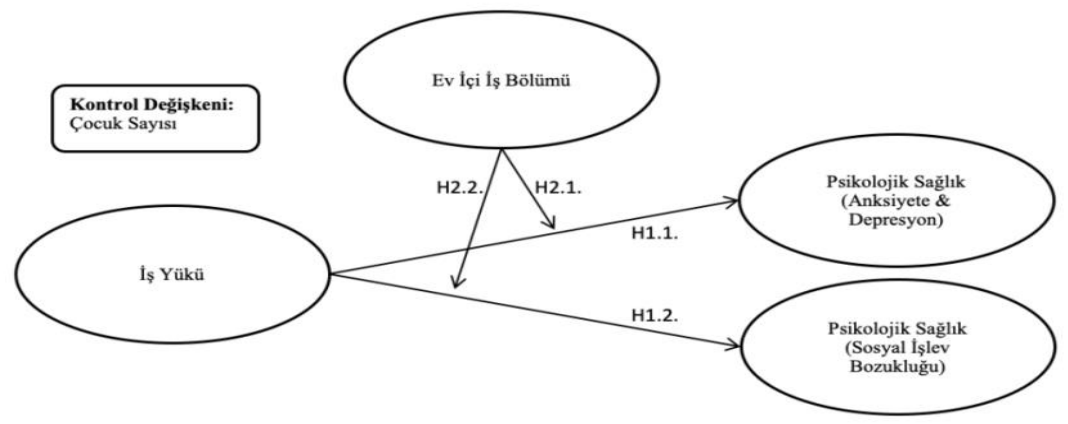

Şekil 1. Araştırma Modeli

\section{Araştırmanın Evreni ve Örneklem}

Araştırma Sanayi ve Teknoloji Bakanlığı'nın 2017 yılında yayınladığı 81 İl Durum Raporunda öne çlkan Türkiye'nin 7 coğrafi bölgesindeki büyük şehirlerde (Adana, Malatya, İzmir, Gaziantep, Ankara, Samsun ve İstanbul) özel sektörde ücretli ve yevmiyeli, kendi hesabına ve işveren olarak çalışan 814 evli ve çocuk sahibi kadın ile gerçekleştirilmiştir. Araştırmaya katılan kadınlar 20-65 yaş grubu aralığında yer almaktadır. Eğitim düzeyleri aç1sindan kadınların \%27,64'ü ilköğretim, \%27,76'sı lise, \%19,91'i ön lisans, $\% 22,23$ 'ü lisans ve $\% 2,45^{\prime} i$ lisansüstü eğitim aldığ1 görülmektedir. Cevaplayıcıların \%11'i yarı zamanlı işlerde, \%89'u tam zamanlı işlerde istihdam edilmektedir. Çalışma süresi açısından ise \%16,21'i 8 saatten az, \%65,61'i 810 saat, \%13,88'i 10-12 saat ve \%4,3'ü 12 saatten fazla günlük çalışma süreleri olduğunu belirtmiştir.

\section{Veri Toplama Araçları}

Psikolojik Sağllk(PS): Goldberg (1972, 1978, 1981) tarafından geliştirilen Genel Sağlık Anketi'nin (GSA) 12 soruluk kısa formu psikolojik sağlık değişkeninin ölçülmesinde kullanılmıştır. Cevaplayıcıların küçük (minör) psikiyatrik bozuklukların belirlenmesinde bireylerin kendilerine uygulayabilecekleri yaygın olarak kullanılan ölçektir (Banks, 1983:349). Cevaplar 4'lü Likert ölçeği ile derecelendirilmiştir (Hiç olmuyor/Her zamanki kadar/Her zamankinden sık/Çok sık). Türkçe uyarlaması Kılıç (1996) tarafından gerçekleştirilmiş, güvenirlik katsayısı 0.84 olarak bulunmuştur.

İş Yükü (IY): 5 ifadelik ve beş noktalı likert ile derecelendirilen ölçek, Spector ve Jex (1997) tarafından geliştirilmiştir. Cevap seçenekleri; Kesinlikle Katıll- 
yorum / Katıliyorum / Kararsızım / Katılmıyorum / Kesinlikle Katılmıyorum şeklindedir. Ölçek, yüksek iş yükü algısını ölçmeye yönelik, "İşimi çok hızlı yapmam gerek", "Elimdeki işleri bitirmek için çok az bir zamanım oluyor" gibi ifadelerden oluşmaktadır. Türkiye'de Keser (2006) ve Gökkaya (2014) tarafından daha önce kullanılmış ve güvenilirlik düzeyi sırasıyla 0.70 ve 0.80 çıkmıştır. Ölçek daha önce Türkiye'de kullanılmış olsa da Türkçesine ulaşılamamış, bu nedenle araştırmacı tarafından Türkçeye çevrilmiştir. Türkçe uyarlama sonrasında 3 uzman akademisyenden görüşleri alınmış ve gerekli düzenlemeler yapılmıştır.

Ev İçi İş Bölümü: Araştırmada belirlenen ev işi gruplarının eşler arası nasıl dağıldığı belirlenmiştir. Bu kapsamda, yemek pişirmek, bulaşıkları yıkamak/makineye yerleştirmek; ev temizliği; ütü; alışveriş; çocukların okula götürülmesi, onlarla oyun oynama, zaman geçirme, hastalıklarında ilgilenme vb. on farklı başlıkta gruplanan ev işlerini kimin yaptı̆̆ sorulmuştur. Yalnızca eşim, genellikle eşim, eşim ve ben, genellikle ben ve yalnızca ben şeklindeki 5 seçenek yer almaktadır ve her bir seçeneğe 1'den 5'e puanlamanın yapıldığı formatif bir ölçek kullanılmıştır. Sorulara verilen cevaplardan hareketle endeks oluşturulmuştur. Bu endekste 1 puan tüm ev işlerinin erkek tarafından yapıldığı sonucunu gösterirken, 5 puan tüm ev işlerinin kadın tarafından yapıldığı sonucuna işaret etmektedir. 3 puan ise ev işlerinin eşit bir şekilde paylaşıldığı durumu göstermektedir.

\section{Analizler}

Araştırma modelinin yansıtmalı ölçekleri olan İş Yükü ve Genel Sağlık Anketi'ne keşfedici faktör analizi uygulanmıştır. Bartlet' in Sphericity test sonuçlarını anlamlı $(, 000)$ ve KMO değerinin $(, 856)$ kabul edilir düzeyde elde edilmesiyle faktör yapıları incelenmiştir. Ortaya çıan 4 faktörlü yapının toplam açıkladığı varyans \%53,603'tür.

Tablo 1. Döndürülmüş Faktör Matrisi

\begin{tabular}{lllll}
\hline & Faktör 1 & Faktör 2 & Faktör 3 & \multirow{2}{*}{ İfade Silindiğinde $(\boldsymbol{\alpha})$} \\
\cline { 2 - 4 } İY1 & $\alpha=0,886$ & $\alpha=0,797$ & $\alpha=0,703$ & 0,861 \\
\hline İY2 & 0,819 & & 0,859 \\
\hline İY3 & 0,833 & & 0,869 \\
\hline İY4 & 0,789 & & 0,86 \\
\hline İY5 & 0,818 & & 0,861 \\
\hline GSA1 & 0,807 & 0,575 & 0,785 \\
\hline GSA2 & & 0,671 & 0,766 \\
\hline GSA6 & 0,629 & 0,777 \\
\hline
\end{tabular}




\begin{tabular}{|c|c|c|c|}
\hline GSA7 & 0,579 & & 0,791 \\
\hline GSA10 & 0,64 & & 0,78 \\
\hline GSA11 & 0,801 & & 0,746 \\
\hline GSA12 & 0,736 & & 0,755 \\
\hline GSA3 & & 0,682 & 0,647 \\
\hline GSA4 & & 0,654 & 0,661 \\
\hline GSA5 & & 0,693 & 0,646 \\
\hline GSA8 & & 0,68 & 0,655 \\
\hline GSA9 & & 0,632 & 0,668 \\
\hline \multicolumn{4}{|c|}{$\begin{array}{l}\text { Extraction Method: Principal Component Analysis. } \\
\text { Rotation Method: Varimax with Kaiser Normalization. } \\
\text { a. Rotation converged in } 5 \text { iterations. }\end{array}$} \\
\hline
\end{tabular}

Her bir faktörün hemen altına o faktöre ait içsel tutarlılık değeri paylaşılmıştır (Tablo 1). Tablonun en sağında yer alan sütunda ise ilgili ifadenin silinmesi halinde ilgili faktörün a değerinin elde edeceği sonuçlar paylaşımıştır. İş yükü ifadeleri orjinaline uygun bir şekilde tek faktör altında gruplanmıştır. 12 ifadelik GSA'nın 3 faktörlü yapısını bazı çalışmalar destekler sonuçlar elde etse de (Graetz, 1991; Sánchez-López ve Dresch, 2008); birçok çalışma gibi (Kılıç vd., 1997; Montazeri vd., 2003; Werneke vd., 2000) bu araştırmada da iki faktörlü bir yapı elde edilmiştir. Elde edilen iki faktör, Werneke vd. (2000) ve Graetz'in (1991) çalışmalarından hareketle; faktör 1: Anksiyete ve Depresyon (A\&D), faktör 2: Sosyal İşlev Bozukluğu (SİB) olarak adlandırılmıştır. Her üç faktörün içsel tutarlılık değeri kabul edilenin üzerindedir ve herhangi bir ifadenin silinmesi halinde bu değerler artmamaktadır.

\section{Doğrulayıcı Faktör Analizi Model Uyum Değerleri}

Doğrulayıcı faktör analizine (DFA) araştırma modelindeki yansıtmalı ölçekler (Genel Sağlık Anketi, İş Yükü Ölçeği) dahil edilirken, formatif ölçek (ev işlerinin eşler arası dağılımı) dahil edilmemiştir ${ }^{1}$. Birincil DFA sonucunda ifadeler teorik olarak varsayılan faktörler altında gruplansalar da kabul edilir model uyum değerlerine sahip olmadıkları gözlemlenmiştir. Modifikasyon endeksindeki bilgiler takip edildiğinde, A\&D boyutuna ait GSA7 ifadesinin SİB boyutu ve bu boyutun alt ifadesi olan GSA9 ile ilişkili olabileceği sonucundan ve GSA1'in de sahip olduğu düşük faktör yükü sebebiyle GSA7 ve GSA1'in analiz dışında tutulmasına karar verilmiştir. Ayrıca yine modifikasyon endeksinden hareketle iş yükünün birinci ve ikinci ifadeleri arasında kovaryansa müsaade edilmiştir.

\footnotetext{
${ }^{1}$ Formatif ve yansıtmalı ölçeklerin karşılaştırması için bkz: Hair vd., 2010, s. 750-754
} 
Devamında DFA'nın tekrarlanması neticesinde elde edilen model uyum değerleri (CMIN/DF:3,405/ GFI:0,953/ CFI:,950/ RMSEA:0,054/ PCLOSE:0,140) kabul edilir düzeydedir. Araştırma modeline ait güvenilirlik değerleri Tablo 2'de paylaşılmıştır. Genel Sağlık Anketinin iki alt boyutu arasında yakınsama geçerliliği anlamında düşük değerler elde edilmiştir. Bu sonuçlar araştırma kısıtlarında paylaşılarak analizlere devam edilmiştir. Nihai DFA sonucunda elde edilen faktör yapılarına ilişkin sonuçlar EK2'de paylaşılmıştır. İş yükü tek boyutta toplanırken, psikolojik sağlık iki alt boyutta (A\&D ve SİB) toplanmıştır.

Tablo 2. Araştırma Modeli Güvenilirlik Değerleri

\begin{tabular}{|c|c|c|c|c|c|c|c|}
\hline & CR & AVE & MSV & $\operatorname{MaxR}(\mathrm{H})$ & SIB & IY & A_D \\
\hline SİB & 0,705 & $\underline{0,324}$ & 0,077 & 0,706 & 0,569 & & \\
\hline IY & 0,882 & 0,6 & 0,14 & 0,883 & 0,277 & 0,774 & \\
\hline A_D & 0,787 & $\underline{0,433}$ & 0,14 & 0,822 & 0,03 & $-0,374$ & 0,658 \\
\hline
\end{tabular}

Hipotez testleri öncesinde çok değişkenli analizler için sağlanması gereken varsayımları kapsamında uçlara kayma ve etkili gözlemlerin belirlenmesi için Cook Uzaklığ istatistiği incelenmiştir. Elde edilen sonuçlar neticesinde hiçbir gözleme ait 1 'in üzerinde değer elde edilmemesi sebebiyle bu varsayımın sağlandığı sonucuna ulaşılmıştır. Bağımlı değişkenler arasında çoklu doğrusal bağlantının (multicollinearity) kontrolü adına ise elde edilen bulgulara göre, VIF (Variance Inflation Factor - Varyans Büyütme Faktörü) skorları (her iki bağımsız değişken için için: 3,859) tolerans değerleri (tüm değişkenler için ,999) kabul edilir düzeydedir (Hair vd., 2010, s.204). Ayrıca araştırma modelindeki tüm değişkenler arası korelasyon değerleri ise EK1 'de paylaşılmıştır.

\section{Bulgular}

Ev içi iş bölümünün dağglımında kadınlar aleyhine belirgin bir eşitsizlik söz konusudur. Ev işlerinin eşler arası dağılımında elde edilen ortalama değer 3,91'dir ( $\mathrm{n}=814)$. Ev işlerinin alt başlıklarından hareketle elde edilen ortalamaların tüm örneklem dahilindeki dağılımı Şekil 2' de paylaşılmıştır. 


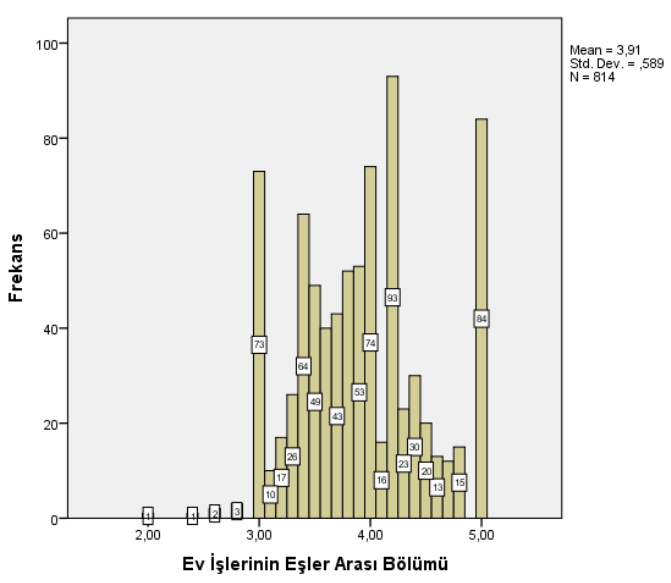

Şekil 2. Ev İçi İşlerin Eşler Arası Dağılımı

Hipotez testleri yürütebilmek için, model uyum değerleri, açılanan toplam varyans ve $p$ değerleri kontrol edilmiştir. Değişkenlerin açıklanan varyansları incelendiğinde, araştırma modelinin bağımlı değişkenlerinin, SİB'nin \%3, A\&D'nin ise \%47'sini açıkladığı görülmektedir. Açılanan varyans düzeyleri kapsamında SİB asgari düzeyin $(\% 2,5)$ üzerinde olmak ile birlikte düşük düzeyde kalmıştır. Model uyum değerleri (CMIN/DF: 2,969 / GFI: 0,994 / CFI: 0,985 / RMSEA: 0,049 / PCLOSE: 0,465) uygun düzeydedir. Analizler sonucunda değişkenler arası elde edilen direk standardize ve standardize edilmemiş regresyon katsayıları ( $\beta$ ) Tablo 3'te paylaşılmıştır.

Tablo 3. Hipotez Test Sonuçları

\begin{tabular}{|c|c|c|c|c|c|c|c|c|c|}
\hline \multirow[b]{3}{*}{ SIB } & \multicolumn{4}{|c|}{ Standardize $\beta$} & \multicolumn{4}{|c|}{ Standardize Edilmemiş $\beta$} & \multirow{2}{*}{$\mathrm{R}^{2}$} \\
\hline & $\dot{\mathrm{I} Y}$ & EIB & İYxEİB & ÇS & $\dot{\mathrm{I} Y}$ & EIB & İYxEİB & ÇS & \\
\hline & $-0,003$ & $-0,095$ & $-0,075$ & $-0,003$ & $-3,056$ & $-0,004$ & $-0,032$ & $-0,011$ & 0,034 \\
\hline$A \& D$ & $-0,677$ & 0,051 & $-0,158$ & $-0,056$ & $-1251,894$ & 0,004 & $-0,039$ & $-0,129$ & 0,468 \\
\hline
\end{tabular}

$\mathrm{p}<.05$ güven aralığında anlamlı ilişkiler ve ilgili değerler "kalın" ile yazılmıştır.

İş yükü algısı psikolojik sağlığın sadece anksiyete \& depresyon boyutu üzerinde $p<.01$ güven aralığında anlamlı bir etkiye $(\beta: 0,677)$ sahip iken sosyal işlev bozukluğu üzerinde anlamlı bir etkiye sahip değildir (Tablo 3). Bu nedenle H1.1. desteklenirken H1.2. desteklenmemiştir.

Ev işlerinin dağılımı iş yükünün anksiyete ve depresyon boyutu üzerindeki negatif etkisinde düzenleyicilik etkisine sahip olduğu ve bu etkiyi arttırdığı gözlemlenmiştir. Böylelikle hipotez 2.1. desteklenirken; iş yükünün SİB üzerinde anlamlı bir etkisi tespit edilememesi nedeniyle, H.2.2. destek- 
lenmemiştir. Ev işleri dağılımının psikolojik sağlı̆̆ın iki alt boyutu üzerindeki direk etkileri incelenmiştir. Bu kapsamda ev işlerinin dağılımı psikolojik sağlığın iki alt boyutu üzerinde $p<.05$ güven aralığında anlamlı etkilere (A\&D üzerinde $\beta: 0,051$; SİB üzerinde ise 0,095) sahiptir. Araştırma modeline kontrol değişkeni olarak eklenen çocuk sayısının ise sadece A\&D boyutu üzerinde $\mathrm{p}<.05$ güven aralığında anlamlı pozitif bir etkiye $(\beta: 0,056)$ sahiptir. Ayrıca çocuk sayısı ve anksiyete ve depresyon tecrübe etme riski arasında, $\mathrm{p}<.01$ güven aralığında ters yönlü bir korelasyon $(-0,2)$ elde edilmiştir. Bu iki sonuç bir arada değerlendirildiğinde, çocuk sayısındaki artışın anksiyete ve depresyon tecrübe etme riskini düşürdüğü, azalmanın ise riski arttırdığ 1 sonucuna ulaşılmıştır.

\section{Sonuç}

Araştırmanın bulguları Goode'un (1960) rol gerginliği teorisini destekler niteliktedir. Rol gerginliği teorisine göre, çoklu rollerin beraberinde getirdiği yüksek beklentilerin, sahip olunan sınırlı enerji ve zaman ile karşılanamadığı durumlarda kadınlar olumsuz sonuçlar ile yüzleşecektir (Goode, 1960; Moen vd., 1992; Hartley vd., 1992; Dennerstein, 1995). Araştırma bulgularında çoklu rol sahibi kadınların, (1) iş yüklerini yüksek olarak algıladığı, (2) ev içi işlerin eşler arasında eşitsiz şekilde dağıldığı, (3) işyükü algılarının anksiyete ve depresyon tecrübe etme riskini ortaya çlkardığ 1 (4) ve bu riskin ev içi işlerin eşitsiz dağılımı ile arttığı sonuçlarına ulaşılmıştır.

İş yükünün kadınlarda anksiyete ve depresyon tecrübe etme riskini arttırdığına yönelik elde edilen sonuç birçok araştırmayı (Gjerdingen ve diğerleri, 2001; Rydstedt ve Johansson 1998; Britt ve Dawson, 2005; Northcott, 1980) destekler niteliktedir. Urhan ve Etiler'in $(2011 ; 204)$ yaptıkları çalışmada ise, sağlık sektöründe çalışan kadınların iş yükü ile birlikte aile ve ev sorumlulukları bir araya geldiğinde daha fazla stres yaşadıkları gözlemlenmiştir. Bu kapsamda elde edilen bulgular literatür ile uyumludur. Aynı zamanda ev içi işlerin eşler arası dağılımının psikolojik sağlığın anksiyete ve depresyon boyutu üzerindeki olumsuz etkisi birçok araştıma sonucu ile benzerlik içindedir (Cleveland vd.,2015; Eek ve Axmon, 2014; Bird, 1999; Harryson vd., 2012). Araştırmanın literatüre temel katkısı bu noktadadır. Farklı gelir ve eğitim kategorilerinden çoklu rol sahibi kadınlar bir arada değerlendirildiğinde, ev içi işler eşler arasında eşitsiz dağılmakta ve eşitsiz dağılım iş yükünün psikolojik sağlık üzerindeki olumsuz etkisini güçlendirmektedir. Bu sonuç çoklu roller arası etkileşimleri daha detaylı bir şekil- 
de ele almamıza imkân tanımaktadır. Çoklu rollerin kadınların omuzlarına yükledikleri yükün ağırlığı kadar bu yükler ekseninde tecrübe edilen eşitsizlikler de araştırmacıların dikkatle takip etmesi gereken bir faktör olarak karşımıza çıkmaktadır.

Öte yandan iş yükünün kadınlarda sosyal işlev bozukluğu tecrübe etme riskini arttırdığına yönelik anlamlı bir etkiye rastlanmamıştır. Türkiye bağlamında kadınların yüksek iş yükü ile karşılaşmasına rağmen sosyal işlev bozukluğu tecrübe etmemelerinde ailelerinden, arkadaşlarından, eşlerinden elde ettikleri sosyal destek ve sosyalleşme olanakları etkili olabilir.

İş yükü algısı psikolojik sağlığın sadece anksiyete \& depresyon boyutu üzerinde $p<.01$ güven aralığında anlamlı bir etkiye $(\beta: 0,677)$ sahip iken sosyal işlev bozukluğu üzerinde anlamlı bir etkiye sahip değildir

Araştırma modelinde kontrol değişkeni olan çocuk sayısı ölçeğinde elde edilen bulgulara göre; tek çocuğu olan kadınların psikolojik sağlıkları, birden fazla çocuğu olan kadınlara göre daha fazla risk altındadır. Detaylı olarak incelendiğinde tek çocuğu olan kadınların çocuklarının ebeveyn kontrölü gerektiren yaşta olduğu gözlemlenmiştir. Elde edilen bulgu, literatürde ebeveyn kontrolü gerektiren yaşta çocuk sahibi olmanın psikolojik sağlık üzerinde baskı yarattığını raporlayan çalışmaları (Arber, 1991; Dennerstein, 1995; Klein, Hyde, Essex, \& Clark, 1998; Gjerdingen \& Chaloner, 1994; Özer, 1995) destekler niteliktedir. Bu sonuç aynı zamanda kadınların iş gücüne katılım oranları ile de ilişkilendirilebilir. Ebeveyn kontrolü gerektiren yaşlarda çocuk sahibi olmanın, kadınların işgücüne katılım oranlarını düşürebildiği gibi (Özer ve Biçerli, 2003-2004; Tansel, 2002) çalışma hayatına devam etmek zorunda olanlar için bu durum psikolojik sağlı̆̆ın risk altına girmesine sebep olmaktadır.

Birçok ülkede farklı kültürel, ekonomik ve sosyal bağlamlarda yapılmış araştırmaların sonuçları ile Türkiye'de gerçekleştirilen bu araştırmada aynı sonuçların elde edilmiş olması ev içi işlerin kadınlar aleyhine dağılımı ve iş yükü ile birlikte aile ve ev içi sorumlulukları aynı anda üstlenmenin sebep olduğu eşitsizliklerin kadınların psikolojik sağlıklarını olumsuz etkilemesi, konunun küresel bir sorun olduğuna işaret etmektedir.

Araştırmanın Kısıtları: Ev içi iş bölümünün dağılımı için kullanılan ölçek yalnızca işlerin kimler tarafından ifa edildiği sorusuna cevap vermektedir ve işlerin eşler arası dağılımının kadınlar tarafından eşitsizlik olarak algılanıp algılanmadığı hakkında ölçüm sunmaması bir araştırma kısıtıdır. Lennon ve Rosenfield'in (1994) çalışması, ev içi iş bölümündeki dengesizliklerin 
kadınlar tarafından eşitsizlik olarak algılanıp algılamamasına göre farklı sonuçlar doğurabildiğini göstermektedir. Bir diğer araştırma kısıtı olarak, doğrulayıcı faktör analizi sonrasında Genel Sağlık Anketinin iki alt boyutu arasında yakınsama geçerliliği anlamında düşük değerler elde edilmesi işaret edilebilir. Bu kısıtın ortaya çıkmasında ise GSA'nın 12 soruluk kısa anketinin yapısal dezavantajları etkili olmuş olabilir (Worsley ve Gribbin 1977). Araştırma sonucunda gözlemlenen bu etkileri yine çoklu rol bütünlüğü içinde ve farklı meslek kategorilerinde test edecek araştırmalara ihtiyaç duyulmaktadır. Gelecek araştırmaların, özellikle farklı gelir ve eğitim düzeylerinden kadınlardan, Genel Sağlık Anketi'nin kısa ve uzun formlarından elde edilecek sonuçları karşılaştırmaları gerektiği düşünülmektedir. Bununla birlikte böylesi bir örneklemi oluşturmak zahmetli olsa da, ev içi işlerin erkekler aleyhine dağılımının gerçekleştiği bir örneklemde de yüksek iş yükü algısına sahip kadınların psikolojik sağlık sonuçlarını inceleyecek gelecek araştırmalara ihtiyaç vardır. 


\title{
EXTENDED ABSTRACT
}

\section{The Effects of Workload on Women's Psychological Health}

\author{
Sevim Ünlü Gezegen \\ Independent Researcher
}

The aim of the study is to test the effect of the workload on the psychological health of women with multiple roles with moderation roles of the division of household labor. To answer this research question this hypothesis are determined:

- H1. Workload perception has a negative effect on psychological health.

- H1.1. Workload perception has a negative effect on the anxiety and depression dimension of psychological health.

- H1.2. Workload perception has a negative effect on social dysfunctioning dimension of psychological health.

- H2. Division of household labor moderates the negative effects of workload on psychological health.

- H2.1. Division of household labor moderates the negative effects of Workload perception on anxiety and depression.

- H2.2. Division of household labor moderates the negative effects of Workload perception on social dysfunctioning.

814 women with multiple roles (working, married, a mother) from seven different cities (Adana, Malatya, İzmir, Gaziantep, Ankara, Samsun ve İstanbul) which are located at Turkey contributed this research. Our sample represents women with multiple roles work in the private sector as hourly-paid workers, casual workers, self-employed, or employers. The ages of the women participating in the study ranged from 2065 . In terms education level, $\% 27,64$ of women have primary education; $\% 27,76$ high school; \%19,91 associates; \%22,23 graduate; and \%2,45 masters's degree. $11 \%$ of respondents are employed in part-time jobs, $89 \%$ in full-time jobs. In terms of Daily working hours, $16,21 \%$ of the sample stated that they work less than 8 hours, $\% 65,61,8-10$ hours, $\% 13,88,10-12$ hours, and $\% 4,3$ more than 12 hours.

According to results, the division of household labor unequally distributed against women. The average is obtained in the distribution of 
household is 3.91 (5 indicates that all household is done by women, 1 indicates that all household is done by men). Unequal distribution is relevant for $\% 84$ of the sample. In terms of household, for the $\% 15$ of the sample household labor distributed equally. And just for the \%1 of the sample household labor distributed unequally against men.

Women's perceived workload is also high (mean: 2,4$)$. In the frame of the research model results point out that, the workload has negative effects on psychological health. The increase in workload noteworthily just increases the risk to experience anxiety and depression $(\beta: 0,677)$. Therefore while hypothesis 1.1 is supported hypothesis 1.2. is not supported. Besides, the inequality in the division of household labor moderates the negative relation between workload and psychological health. In other words, the inequality in the division of household labor increases the negative effects of workload on anxiety and depression dimension of psychological health. So hypothesis 2.1. is supported. Hypothesis 2.2. could not be tested because there was no significant effect of workload on the social dysfunctioning dimension of psychological health.

In terms of direct effects of a moderator on the dependent variable, unequal distribution of household labor has significant effects on both anxiety/depression $(p<.05 ; \beta: 0,051)$ and social dysfunctioning $(p<.05 ; \beta$ : $0,095)$. According to the findings in the frame of "number child" which is included in the research model as control variable, the psychological health of women having a single child is at higher risk than women having more than one child. The number of children has a significant positive effect $(p<.05 ; \beta: 0,056)$ just on anxiety and depression dimension. Besides negative correlation ( $\mathrm{r}:-0.2)$ is obtained between the number of children and the risk of experiencing "anxiety and depression" at $\mathrm{p}<.01$ confidence level. In the frame of these two findings, it has been concluded that an increase in the number of children reduces the risk of experiencing anxiety and depression, while a decrease increases the risk.

When these findings evaluated in detail, it was observed that the children of women waving only one child were of the age requiring a high degree of parental care. This finding is supportive fort he literature (Arber, 1991; Dennerstein, 1995; Klein, Hyde, Essex, \& Clark, 1998; Gjerdingen \& Chaloner, 1994; Özer, 1995) highlighting that having children at an age requires a high level of parental care puts pressure on psychological health. While having children at those ages also decrease wo- 
men's labor force participation (Özer and Biçerli, 2003-2004; Tansel, 2002); for those who have to be in working life, this causes the reality that women's psychological health being at risk.

Limitations: The scale which is used for the division of household labor between parents does not provide an answer that whether this distribution is perceived as inequality by women. As Lennon and Rosenfield (1994) highlight, the different perceptions related to unequal distribution of household labor might have different results. So this is one of the limitations of the study. As another research limitation, with the results of confirmatory factor analysis low values were obtained in the frame of convergent validity between two sub-dimensions of the general health questionnaire. As Worsley and Gribbin 1977 point out structural critiques of the short version of the General Health Questionnaire (12 items) may have been effective for this limitation. In my opinion future studies need to compare results obtained from short and long versions of the General Health Questionnaire with a sample consisting of women with multiple roles and different income and education levels.

\section{Kaynakça / References}

Ahmad-Nia, S. (2002). Women's work and health in Iran: A comparison of working and non-working mothers. Social Science ve Medicine, 54(5), 753-765. Https://Doi.Org/Https://Doi.Org/10.1016/S0277-9536(01)00107-1

Arber S. 1991. Class, paid employment and family roles: making sense of structural disadvantage, gender, and health status. Soc. Sci. Med. 32, 425-36

Arber, S. (1997). Comparing inequalities in women's and men's health: Britain in The 1990s. Social Science ve Medicine, 44(6), 773-787. Https://Doi.Org/Https://Doi.Org/10.1016/S0277-9536(96)00185-2

Arber, S., Gilbert, G. N., ve Dale, A. (1985). Paid employment and women's health: A benefit or a source of role strain? Sociology Of Health ve Illness, 7(3), 375-400. Https:/Doi.Org/10.1111/1467-9566.Ep10834014

Aycan, Z., ve Eskin, M. (2005). Relative contributions of childcare, spousal support, and organizational support in reducing work-family conflict for men and women: The case of Turkey. Sex Roles, 53(7), 453-471. Https://Doi.Org/10.1007/S11199$\underline{005-7134-8}$

Banks, M. H. (1983). Validation of the general health questionnaire in a young community sample. Psychological Medicine, 13(2), 349-353. Https:/Doi.Org/DOI: 10.1017/S0033291700050972 
Banks, M. H., Clegg, C. W., Jackson, P. R., Kemp, N. J., Stafford, E. M., ve Wall, T. D. (1980). The use of the general health questionnaire as an indicator of mental health in occupational studies. Journal Of Occupational Psychology, 53(3), 187-194. Https://Doi.Org/10.1111//.2044-8325.1980.Tb00024.X

Barnett, R. C., ve Marshall, N. L. (1992). Worker and mother roles, spillover effects, and psychological distress. Women ve Health, 18(2), 9-40. Https://Doi.Org/10.1300//013v18n02 02

Baruch, G. K., ve Barnett, R. (1986). Role quality, multiple role involvement, and psychological well-being in midlife women. Journal Of Personality And Social Psychology, 51(3), 578-585. Https://Doi.Org/10.1037/0022-3514.51.3.578

Baxter, J., ve Tai, T. (2016). Inequalities in unpaid work: A cross-national comparison. In M. L. Connerley ve J. Wu (Eds.), Handbook On Well-Being Of Working Women, içinde (s.653-671). Dordrecht: Springer Netherlands. Https://Doi.Org/10.1007/978-94-017-9897-6 36

Bernstein, A. B. (2001). Motherhood, health status, and health care. Women's Health Issues, 11(3), 173-184. Https://Doi.Org/Https://Doi.Org/10.1016/S1049-3867(01)00078-0

Bird, C. E. (1999). Gender, household labor, and psychological distress: The impact of the amount and division of housework. Journal of Health and Social Behavior. 40(1), US: American Sociological Assn. Https://Doi.Org/10.2307/2676377

Britt, T. W. ve Dawson, C. R. (2005). Predicting work: Family conflict from workload, job attitudes, group attributes, and health: A Longitudinal Study. Military Psycho$\log y, 17,203-227$.

Cleveland, J. N., Fisher, G. G. Ve Sawyer, K. B. (2015). Work-life equality: The importance of a level playing field at home bt. In M. J. Mills (Ed.), Gender And The WorkFamily Experience: An Intersection Of Two Domains içinde (s.177-199). Cham: Springer International Publishing. Https://Doi.Org/10.1007/978-3-319-08891$\underline{4} 10$

Dağdeviren, M., Eraslan E. ve Kurt,M. (2005). Çalışanların toplam iş yükü seviyelerinin belirlenmesine yönelik bir model uygulaması. Gazi Üniversitesi Mühendislik Mimarlk Fakültesi Dergisi, 20(4), 517-525.

Dedeoğlu, S., ve Öztürk, M. Y. (2010). Kapitalizm, ataerkillik ve kadn emeği: Türkiye örneği. İstanbul: Sav Yayinclik.

Dennerstein, L. (1995). Mental health, work, and gender. International Journal Of Health Services, 25(3), 503-509. Https://Doi.Org/10.2190/Q/RA-8NMB-KR1R-QH4Q

Dökmen, Z. Y. (2003). Çalişma durumlari farkli üç grup kadinda ruh sağliği, kontrol odağ inanci ve cinsiyet rolü. Türk Psikoloji Dergisi, 18(51), 111-127.

Dugan A. G. ve Barnes-Farrell J. L., (2018). Working mothers' second shift, personal resources, and self-care. Community, Work \& Family, 1-17 DOI:10.1080/13668803.2018.1449732 
Dünya Sağllk Örgütü (2018) Mental health: strengthening our response https://www.who.int/news-room/fact-sheets/detail/mental-healthstrengthening-our-respo

Eek, F., ve Axmon, A. (2014). Gender inequality at home is associated with poorer health for women. Scandinazian Journal of Public Health, 43(2), 176-182. Https://Doi.Org/10.1177/1403494814562598

Etiler, N. (2015). Çalışan kadınlar ile ev kadınlarının sağlık durumu üzerine bir analiz. Mesleki Sağlk Ve Güvenlik Dergisi (MSG), 15(57).

Froberg, D., Gjerdingen, D. K., ve Preston, M. (1986). Multiple roles and women's mental and physical health. Women ve Health, 11(2), 79-96. Https://Doi.Org/10.1300//013v11n02 06

Geurts, S. A. E., Kompier, M. A. J., Roxburgh, S., ve Houtman, I. L. D. (2003). Does workhome interference mediate the relationship between workload and well-being? Journal of Vocational Behavior, 63, 532-559.

Gjerdingen, D.K., Chaloner, K.M., (1994). The relationship of women's postpartum mental health to employment, childbirth, and social support. Journal of Family Practice, 38(5), 465-472.

Glass, J., ve Fujimoto, T. (1994). Housework, paid work, and depression among husbands and wives. Journal Of Health And Social Behavior, 35(2), 179-191. Https://Doi.Org/10.2307/2137364

Glynn, K., Maclean, H., Forte, T., ve Cohen, M. (2009). The association between role overload and women's mental health. Journal of Women's Health, 18(2), 217-223. doi:10.1089/jwh.2007.0783

Gökkaya, Ö. (2014). Yerel yönetimlerde iş-yaşam dengesi ve çalışan davranışı ilişkisinin incelenmesi: Kocaeli Belediyeler örneği. Elektronik Mesleki Gelişim ve Araştırmalan Dergisi, 2, 2-18.

Goldberg, D. P. (1972). The detection of psychiatric illness by questionnaire. Maudsley Monograph No. 21. London: Oxford University Press.

Goldberg, D. P. (1978). Manual of the general health questionnaire, NFER. Windsor: NFER Publishing Company.

Goode, W. J., (1960). A theory of role strain. American Sociological Review, 25(4), 483-496. Https://Doi.Org/10.2307/2092933

Gove, W. R., ve Tudor, J. F. (1973). Adult sex roles and mental illness. American Journal Of Sociology, 78(4), 812-835. Https://Doi.Org/10.1086/225404

Graetz, B. (1991). Multidimensional properties of the general health questionnaire. Social Psychiatry And Psychiatric Epidemiology, 26(3), 132-138. Https://Doi.Org/10.1007/BF00782952 
Griffin, J. M., Fuhrer, R., Stansfeld, S. A., ve Marmot, M. (2002). The importance of low control at work and home on depression and anxiety: Do these effects vary by gender and social class? Social Science ve Medicine, 54(5), 783-798. Https://Doi.Org/Https://Doi.Org/10.1016/S0277-9536(01)00109-5

Gutek, B. A., Searle, S., ve Klepa, L. (1991). Rational versus gender role explanations for work-family conflict. Journal Of Applied Psychology, 76(4), 560-568. Https://Doi.Org/10.1037/0021-9010.76.4.560

Hair, J. F. J., Black, W. C., Babin, B. J., ve Anderson, R. E. (2010). Multivariate data analysis: A global perspective. (7th Ed.). Upper Saddle River, Boston Columbus: Pearson.

Hammarström, A., ve Phillips, S. P. (2012). Gender inequity needs to be regarded as a social determinant of depressive symptoms: Results from the Northern Swedish Cohort. Scandinazian Journal of Public Health, 40(8), 746-752. Https://Doi.Org/10.1177/1403494812464915

Harryson, L., Strandh, M., ve Hammarström, A. (2012). Domestic work and psychological distress: What is the importance of relative socioeconomic position and gender inequality in the couple relationship? Plos One, 7(6), E38484-E38484. Https:/Doi.Org/10.1371//ournal.Pone.0038484

Hartley, M., Popay, J., ve Plewis, I. (1992). Domestic Conditions, paid employment and women's experience of 1ll-health. Sociology of Health \& Illness, 14(3), 313-343. Https://Doi.Org/10.1111//.1467-9566.1992.Tb00126.X

Hibbard, J. H. ve Pope, C. R. (1991). Effect of domestic and occupational roles on morbidity and mortality. Social Science \& Medicine, 32(7), 805-811.

Hochschild, A., ve Machung, A. (2012). The second shift: Working families and the revolution at home. Penguin.

TÜIKK. (2015). Zaman kullanmm araştrması. http://www.tuik.gov.tr/PreHaberBultenleri.do?id=18627 adresinden erişilmiştir.

Karatepe, O. M. (2013). The effects of work overload and work-family conflict on job embeddedness and job performance: The mediation of emotional exhaustion. International Journal of Contemporary Hospitality Management, 25(4), 614-634.

Keser, A. (2006). Çağrı merkezi çalş̧anlarında iş yükü düzeyi ile iş doyumu ilişkisinin araştrılması. Kocaeli Üniversitesi Sosyal Bilimler Enstitïiü Dergisi, 100-119.

Kılıç, C., Rezaki, M., Rezaki, B., Kaplan, I., Özgen, G., Sağduyu, A., ve Öztürk, M. O. (1997). General health questionnaire (GHQ12 ve GHQ28): Psychometric properties and factor structure of the scales in a Turkish primary care sample. Social Psychiatry And Psychiatric Epidemiology, 32(6), 327-331.

Kinnunen, U., ve Mauno, S. (1998). Antecedents and outcomes of work-family conflict among employed women and men in Finland. Human Relations, 51(2), 157-177. Https://Doi.Org/10.1177/001872679805100203 
Klein, M.H., Hyde, J.S., Essex, M.J. ve Clark, R., (1998). Maternity leave, role quality, work involvement, and mental health one year after delivery. Psychology of Women Quarterly, 22, 239-266.

Kopp, R. G., ve Ruzicka, M. F. (1993). Women's multiple roles and psychological wellbeing. Psychological Reports, 72(3_Suppl), 1351-1354. Https://Doi.Org/10.2466/Pr0.1993.72.3c.1351

Lennon, M. C., ve Rosenfield, S. (1994). Relative fairness and the division of housework: The importance of options. American Journal Of Sociology, 100(2), 506-531. Https://Doi.Org/10.1086/230545

Lordoğlu, K, veÖzkaplan, N. (2005). Çalı̧̧ma iktisadı. İstanbul: Der Yayınları

Madsen, S. R. (2001). Work and family conflict: A review of the theory and literature. Tulsa, Oklahoma: Academy Of Human Resource Development Conference Proceedings (Symposium 22)

Madsen, S. R. (2003). The effects of home-based teleworking on work-family conflict. Human Resource Development Quarterly, 14(1), 35-58. Https://Doi.Org/10.1002/Hrdq.1049

Mcbride, A. B. (1990). Mental health effects of women's multiple roles. Addictions Nursing Network, 2(3), 4-14. Https://Doi.Org/10.3109/10884609009149669

Mcnamara, M., Bohle, P., ve Quinlan, M. (2011). Precarious employment, working hours, work-life conflict and health in hotel work. Applied Ergonomics, 42(2), 225232. Https://Doi.Org/Https://Doi.Org/10.1016/J.Apergo.2010.06.013

Meijman, T. F. ve Mulder, G. (1998). Psychological aspects of workload. In Handbook of Work and Organizational: Work Psychology içinde (cilt: 2, 2nd Ed., s.5-33), Hove, England: Psychology Press/Erlbaum (UK) Taylor \& Francis.

Memiş, E., ve Özay, Ö. (2011). Eviçi uğraşlardan iktisatta karşlıksız emeğe: Türkiye üzerine yapılan çalışmalara ilişkin bir değerlendirme. In S. Sancar (Ed.), Birkaç Arpa Boyu içinde(Vol. 21, 249-280). İstanbul: Koç Üniversitesi Yayınları

Moen, P., Dempster-Mcclain, D., ve Williams Robin M. (1992). Successful aging: A lifecourse perspective on women's multiple roles and health. American Journal Of Sociology, 97(6), 1612-1638. Https://Doi.Org/10.1086/229941

Molarius, A., Granström, F., Lindén-Boström, M., ve Elo, S. (2013). Domestic work and self-rated health among women and men aged 25-64 years: Results from a population-based survey in Sweden. Scandinavian Journal of Public Health, 42(1), 52-59. Https://Doi.Org/10.1177/1403494813503056

Montazeri, A., Harirchi, A. M., Shariati, M., Garmaroudi, G., Ebadi, M., ve Fateh, A. (2003). The 12-item general health questionnaire (GHQ-12): Translation and validation study of the Iranian version. Health And Quality Of Life Outcomes, 1(1), 66. Https://Doi.Org/10.1186/1477-7525-1-66. 
Nathanson, C. A. (1980). Social roles and health status among women: The significance of employment. Social Science ve Medicine. Part A: Medical Psychology ve Medical Sociology, 14(6), 463-471. Https:/Doi.Org/Https://Doi.Org/10.1016/S02717123(80)80050-2

Noor, N. M. (2004). Work-family conflict, work- and family-role salience, and women's well-being. The Journal of Social Psychology, 144(4), 389-406. Https://Doi.Org/10.3200/SOCP.144.4.389-406

Northcott, H. C. (1980). Women, work, and health. The Pacific Sociological Review, 23(4), 393-404. doi:10.2307/1388732

Ozer, E. M. (1995). The impact of childcare responsibility and self-efficacy on the psychological health of professional working mothers. Psychology of Women Quarterly, 19(3), 315-335. https://doi.org/10.1111/j.1471-6402.1995.tb00078.x

Perry-Jenkins, M., ve Folk, K. (1994). Class, couples, and conflict: Effects of the division of labor on assessments of marriage İn Dual-Earner Families. Journal Of Marriage And Family, 56(1), 165-180. Https://Doi.Org/10.2307/352711

Qureshi, M. I., Iftikhar, M., Abbas, S. G., Hassan, U., Khan K. ve Zaman, K. (2013). Relationship between job stress, workload, environment and employees turnover intentions: What we know, what should we know. World Applied Sciences Journal, 764-770. DOI: 10.5829/idosi.was.2013.23.06.313

Reskin, B. F., ve Coverman, S. (1985). Sex and race in the determinants of psychophysical distress: A reappraisal of the sex-role hypothesis. Social Forces, 63(4), 1038-1059. Https://Doi.Org/10.1093/Sf/63.4.1038

Roxburgh, S., 1997. The Effect of children on the mental health of women in the paid labor force. Journal of Family Issues 18(3), 270-289.

Ruderman, M. N., Ohlott, P. J., Panzer, K., ve King, S. N. (2002). Benefits of multiple roles for managerial women. Academy Of Management Journal, 45(2), 369-386. Https://Doi.Org/10.5465/3069352

Rydstedt, L. W., Johansson, G., ve Evans, G. W. (1998). A longitudinal study of workload, health and well-being among male and female urban bus drivers. Journal of Occupational \& Organizational Psychology, 71, 35-45.

Sánchez-López, M. Del P., ve Dresch, V. (2008). The 12-1tem general health questionnaire (GHQ-12): Reliability, External validity and factor structure in the spanish population. Psicothema, 20(4), 839-843.

Sanz-Vergel, A. I., Demerouti, E., Bakker, A. B., ve Moreno-Jiménez, B. (2011). Daily detachment from work and home: The moderating effect of role salience. $\mathrm{Hu}$ man Relations, 64(6), 775-799. Https://Doi.Org/10.1177/0018726710393368

Savran, G. A., ve Demiryontan, N. T. (2008). Kadının görünmeyen emeği. İstanbul: Yordam Kitap. 
Sharma, J., Dhar, R. L., ve Tyagi, A. (2016). Stress as a mediator between work-family conflict and psychological health among the nursing staff: Moderating role of emotional intelligence. Applied Nursing Research, 30, 268-275. Https://Doi.Org/Https://Doi.Org/10.1016/.Apnr.2015.01.010

Shelton, B. A., ve John, D. (1996). The division of household labor. Annual Review Of Sociology, 22(1), 299-322. Https://Doi.Org/10.1146/Annurev.Soc.22.1.299

Sieber, S. D. (1974). Toward a theory of role accumulation. American Sociological Review, 39(4), 567-578. Https://Doi.Org/10.2307/2094422

Sorensen, G., ve Verbrugge, L. M. (1987). Women, work, and health. Annual Review Of Public Health, $8(1)$, 235-251. Https://Doi.Org/10.1146/Annurev.Pu.08.050187.001315

Staland-Nyman, C., Alexanderson, K., ve Hensing, G. (2008). Associations between strain in domestic work and self-rated health: A study of employed women in Sweden. Scandinazian Journal Of Public Health, 36(1), 21-27. Https://Doi.Org/10.1177/1403494807085307

Svedberg, P., Mather, L., Bergström, G., Lindfors, P., ve Blom, V. (2018). Work-home interference, perceived total workload, and the risk of future sickness absence due to stress-related mental diagnoses among women and men: A prospective twin study. International Journal Of Behavioral Medicine, 25(1), 103-111. Https://Doi.Org/10.1007/S12529-017-9669-9

Thoits, P. A. (1983). Multiple identities and psychological well-being: A reformulation and test of the social solation hypothesis. American Sociological Review, 48(2), 174-187. Https://Doi.Org/10.2307/2095103

Urhan, B., ve Etiler, N. (2011). Sağlk sektöründe kadın emeğinin toplumsal cinsiyet açısından analizi. Çalışma Ve Toplum, 2(29), 191-215.

Verbrugge, L. M. (1986). Role Burdens And Physical Health Of Women And Men. Women ve Health, 11(1), 47-77. Https://Doi.Org/10.1300/J013v11n01 04

Verdonk, P., Hooftman, W. E., Van Veldhoven, M. J. P. M., Boelens, L. R. M., ve Koppes, L. L. J. (2010). Work-related fatigue: The specific case of highly educated women in the Netherlands. International Archives Of Occupational And Environmental Health, 83(3), 309-321. Https://Doi.Org/10.1007/S00420-009-0481-Y

Voydanoff, P., ve Donnelly, B. W. (1999). multiple roles and psychological distress: The intersection of the paid worker, spouse, and parent roles with the role of the adult child. Journal of Marriage And Family, 61(3), 725-738. Https://Doi.Org/10.2307/353573

Waldron, I, ve Jacobs, J. A. (1988). Effects of labor force participation on women's health: New evidence from a longitudinal study. Journal Of Occupational Medicine.: Official Publication Of The Industrial Medical Association, 30(12), 977-983. Https://Doi.Org/10.1097/00043764-198812000-00019 
Waldron, I., Hughes, M. E., ve Brooks, T. L. (1996). Marriage protection and marriage selection: Prospective evidence for reciprocal effects of marital status and health. Social Science ve Medicine, 43(1), 113-123. Https://Doi.Org/Https://Doi.Org/10.1016/0277-9536(95)00347-9

Waldron, I., ve Jacobs, J. A. (1989). Effects of multiple roles on women's health: Evidence from a national longitudinal study. Women ve Health, 15(1), 3-20. Https://Doi.Org/10.1300/J013v15n01 02

Waldron, I., Weiss, C. C., ve Hughes, M. E. (1998). Interacting effects of multiple roles on women's health. Journal Of Health And Social Behavior, 39(3), 216-236. Https://Doi.Org/10.2307/2676314

Werneke, U., Goldberg, D. P., Yalcm, I., ve Üstün, B. T. (2000). The stability of the factor structure of the general health questionnaire. Psychological Medicine, 30(4), 823829. Https://Doi.Org/DOI: 10.1017/S0033291799002287

Worsley, A., ve Gribbin, C. C. (1977). A factor analytic study of the twelve item general health questionnaire. Australian \& New Zealand Journal of Psychiatry, 11(4), 269272.

\section{Ekler}

EK1: Araştırma Modeli Değişkenler Arası Korelasyonlar

\begin{tabular}{|c|c|c|c|c|c|c|}
\hline \multirow[b]{2}{*}{ İY } & IY & SİB & A_D & EY & ÇS & IY_x_EY \\
\hline & 1 & & & & & \\
\hline SİB & 0,022 & 1 & & & & \\
\hline A_D &,$- 675^{* *}$ &, $228^{* *}$ & 1 & & & \\
\hline EY_Likert & $-0,035$ &,$- 086^{*}$ &, $076^{*}$ & 1 & & \\
\hline ÇS &, $110^{* *}$ & $-0,011$ &,$- 200^{* *}$ & 0,017 & 1 & \\
\hline İY_x_EY &,$- 146^{* *}$ &,$- 152^{* *}$ & 0,022 & $-0,06$ & $-0,014$ & 1 \\
\hline
\end{tabular}

EK2: Doğrulayıcı Faktör Analizi: Standardize / Stand. Edilmemiş Regresyon Yükleri ve Çoklu Korelasyonlarn Karesi

\begin{tabular}{|c|c|c|c|c|c|c|c|}
\hline \multirow[b]{3}{*}{ İY 5} & \multicolumn{3}{|c|}{ Standardize } & \multicolumn{3}{|c|}{ Standardize Edilmemiş } & \multirow[t]{2}{*}{ ÇKK } \\
\hline & İY & $A \& B$ & siB & İY & $A \& B$ & Sï & \\
\hline & 0,802 & & & 1 & & & 0,643 \\
\hline İY 4 & 0,799 & & & 1,016 & & & 0,638 \\
\hline İY 3 & 0,752 & & & 0,928 & & & 0,566 \\
\hline İY 2 & 0,759 & & & 1,004 & & & 0,576 \\
\hline İY 1 & 0,758 & & & 0,905 & & & 0,575 \\
\hline P_S12 & & 0,768 & & & 1 & & 0,59 \\
\hline P_S11 & & 0,801 & & & 1,023 & & 0,642 \\
\hline P_S10 & & 0,523 & & & 0,626 & & 0,274 \\
\hline P_S6 & & 0,509 & & & 0,66 & & 0,259 \\
\hline P_S2 & & 0,634 & & & 0,909 & & 0,402 \\
\hline P_S9 & & & 0,537 & & & 1 & 0,288 \\
\hline P_S8 & & & 0,57 & & & 1,043 & 0,325 \\
\hline P_S5 & & & 0,592 & & & 1,13 & 0,35 \\
\hline
\end{tabular}




\begin{tabular}{lcrl} 
P_S4 & 0,548 & 1,068 & 0,3 \\
\hline P_S3 & 0,595 & 1,065 & 0,354 \\
\hline Not: Kalın ile yazılanlar istatistiki olarak anlamlı $\mathrm{p}<.01$ & & \\
\hline
\end{tabular}

EK3: Her bir gizil değişkene ait ifadelerin Korelasyon, ortalama ve standart sapma değerleri

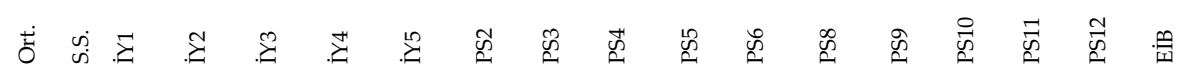

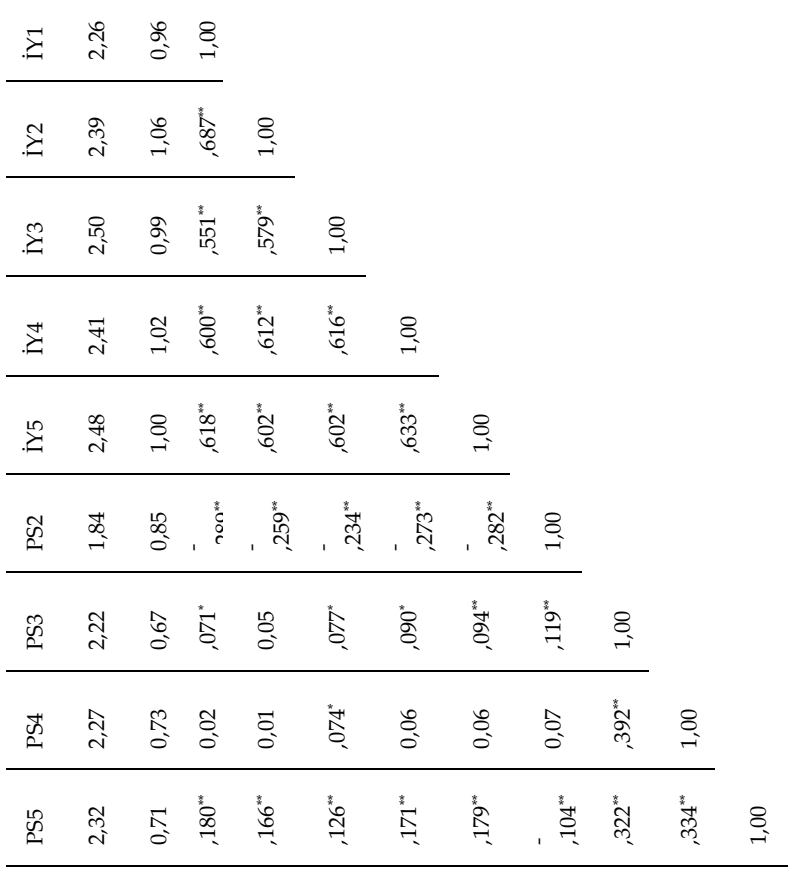

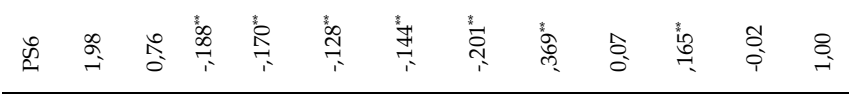

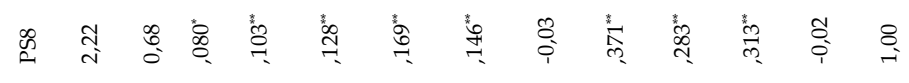

की

员 点

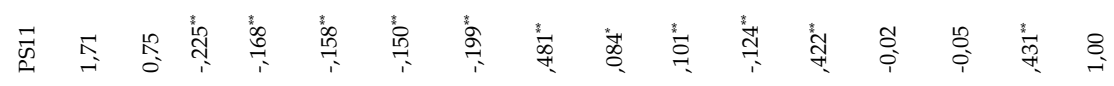




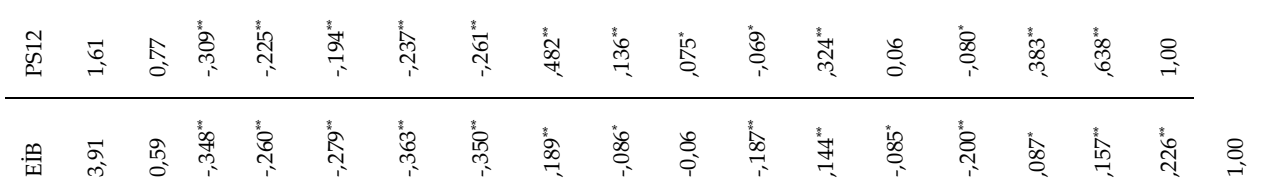

**. Korelasyon 0.01 düzeyinde anlamlı (2-tailed).

*. Korelasyon 0.05 düzeyinde anlamlı (2-tailed).

\section{Kaynakça Bilgisi / Citation Information}

Ünlü Gezegen, S. (2021). İş yükünün kadınların psikolojik sağlığı üzerine etkisinde ev içi iş bölümünün düzenleyicilik etkisi. OPUSUluslararası Toplum Araştırmaları Dergisi, 17(33), 193-220. DOI: 10.26466/opus.756225 